\title{
Meiotic control of the APC/C: similarities \& differences from mitosis
}

\author{
Katrina F Cooper ${ }^{*}$ and Randy Strich
}

\begin{abstract}
The anaphase promoting complex is a highly conserved E3 ligase complex that mediates the destruction of key regulatory proteins during both mitotic and meiotic divisions. In order to maintain ploidy, this destruction must occur after the regulatory proteins have executed their function. Thus, the regulation of APC/C activity itself is critical for maintaining ploidy during all types of cell divisions. During mitotic cell division, two conserved activator proteins called Cdc20 and Cdh1 are required for both APC/C activation and substrate selection. However, significantly less is known about how these proteins regulate APC/C activity during the specialized meiotic nuclear divisions. In addition, both budding yeast and flies utilize a third meiosis-specific activator. In Saccharomyces cerevisiae, this meiosis-specific activator is called Ama1. This review summarizes our knowledge of how Cdc20 and Ama1 coordinate APC/C activity to regulate the meiotic nuclear divisions in yeast.
\end{abstract}

\section{Meiosis and gametogenesis}

The proper segregation of chromosomes at meiosis I and II is essential for producing gametes with the correct haploid genome (Figure 1). During oogenesis, meiotic progression is arrested at the first or second division during development. Maturation of the oocytes or fertilization is required to relieve these blocks, respectively. Spermatogenesis is a continuous process that occurs throughout most of the life of the male. Yeast sporulation possesses the hallmarks of mammalian meiosis and is similar to spermatogenesis in that the process does not exhibit programmed arrest points. In Saccharomyces cerevisiae, entry into the meiotic program is dependent upon cell-type and environmental clues [1]. Following induction, premeiotic DNA replication occurs followed by a lengthy prophase in which homologous chromosomes synapse and undergo a high level of genetic recombination prior to meiosis I ([2] \& Figure 1). This genetic exchange is essential for chromosomes to correctly align at metaphase $\mathrm{I}$. It is during meiosis $\mathrm{I}$, the reductional division, that the sister chromatids remain paired, attach to only one spindle, and segregate together. This centromeric cohesion is lost during the second meiotic division, which resembles mitosis, where the replicated sisters make bipolar attachments and

\footnotetext{
* Correspondence: cooperka@umdnj.edu

University of Medicine and Dentistry of New Jersey, 2 Medical Center Drive, Stratford, NJ 08055, USA
}

separate to opposite poles [3]. The resulting four haploid nuclei are each encased in a multi-layered structure called a spore that remains dormant until induced to reenter mitotic cell division by growth signals [1]. Thus, the monopolar attachment of replicated sister chromatids at meiosis I and the execution of two nuclear divisions without an intervening $\mathrm{S}$ phase represent two major differences between meiotic and mitotic divisions.

\section{Specialized control of mitotic cell cycle machinery required for meiotic nuclear divisions}

The basic cell cycle machinery driving mitotic cell division (e.g., DNA polymerases, cyclin dependent kinases, ubiquitin ligases) is also required to execute meiosis. However, meiosis presents several challenges that are not found during mitosis such as maintaining sister chromatid attachment during the reductional division or undergoing two nuclear divisions without an intervening $S$ phase. Studies in S. cerevisiae have identified two strategies by which the mitotic cell cycle machinery is redirected to execute the meiotic divisions. The first method involves replacing mitotic regulatory proteins with meiotic counterparts. For example, Rec8 replaces Mcd1 to maintain sister centromere cohesion during meiosis I [4]. In addition, Ama1 is a meiosis-specific activator of the anaphase promoting complex/cyclosome (APC/C) ubiquitin ligase and is required for exit from meiosis II [5-8]. The second approach utilizes mitotic regulators 


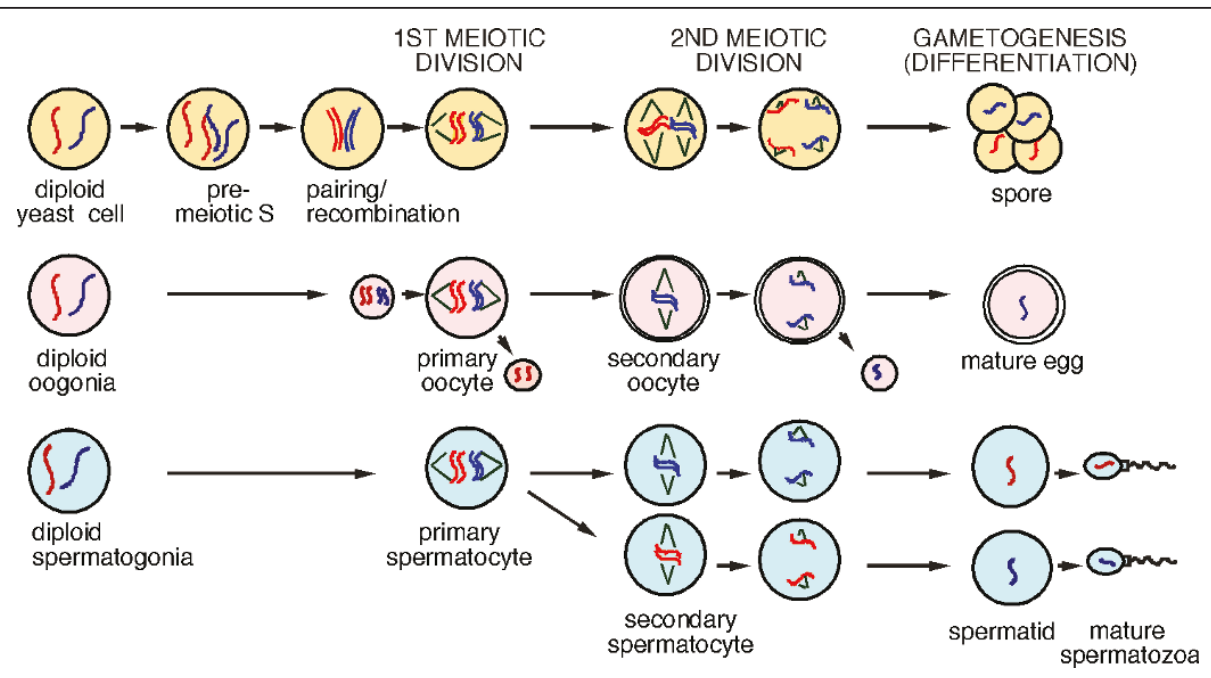

Figure 1 Meiotic divisions are conserved between yeast and higher eukaryotes including mammals. Cartoon showing the similarities between the meiotic divisions in yeast and mammals. The red and the blue lines represent chromosomes. Pre-meiotic S, pairing and recombination occur in oogenesis and spermatogenesis but have only been drawn for meiosis in yeast for clarity.

that take on new meiotic functions. For example, the mitotic S-phase cyclins Clb5 and Clb6 are required for the initiation of recombination and synaptoneal complex formation during meiosis [9]. Furthermore, the APC/ $\mathrm{C}^{\mathrm{Cdc} 20}$ ubiquitin ligase that controls the G2/M transition in mitotic cells also has a meiosis-specific role to induce early meiotic gene transcription as well as progression through prophase I $[8,10,11]$. The focus of this review is to summarize our knowledge of how the APC/C regulates, and how it is regulated by, the meiotic differentiation program in the model system S. cerevisiae.

\section{Role of APC/C activators during mitotic division}

To examine the regulation and activity of $\mathrm{APC} / \mathrm{C}^{\mathrm{Cdc} 20}$ during meiosis, it is helpful to first start with what is known about this ligase's function and regulation during mitotic cell division. The $\mathrm{APC} / \mathrm{C}$ is a multi-subunit ubiquitin ligase that directs the destruction of cell cycle regulatory proteins at the metaphase-anaphase transition, exit from mitosis, and G1 [12]. The control of APC/C activity and specificity is complex (for reviews see [13-16]). During mitotic cell division, APC/ $\mathrm{C}$ activation depends on its sequential association with two evolutionarily conserved coactivators, Cdc20 and Cdh1 (Figure 2). In brief, in the presence of high cyclin dependent kinase (Cdk) activity, Cdc20 activated APC/ $\mathrm{C}\left(\mathrm{APC} / \mathrm{C}^{\mathrm{Cdc} 20}\right)$ promotes the metaphase-anaphase transition by directing the destruction of the anaphase inhibitor Pds1/securin [17-20] causing subsequent dissolution of the cohesin complex holding the sister chromatids together (see [21] and references therein). After anaphase, APC/C $\mathrm{C}^{\mathrm{Cdh} 1}$ mediates the final degradation of mitotic B-type cyclins and several other proteins [22-27] as the cell exits mitosis and enters G1. In $S$ phase and G2, the APC/C is inactive to allow accumulation of proteins required for building the mitotic spindle.

\section{Regulation of Cdc20 during mitotic cell division}

APC/C mediated proteolysis of key regulatory proteins drives the cell from $G 2$ through $M$ phase into $G 1$. Accordingly, the APC/C is under a strict temporal control so these targets are destroyed in the correct order. Toward this end, $\mathrm{APC} / \mathrm{C}^{\mathrm{Cdc} 20}$ is regulated by at least four mechanisms. First, Cdc20 levels are modulated by transient transcription from $\mathrm{S}$ phase through G2 phase and proteolysis in G1 [28,29]. Once associated, APC/ $\mathrm{C}^{\mathrm{Cdc} 20}$ is inhibited in $\mathrm{G} 2$ by Mad2p, a component of the spindle assembly checkpoint (SAC) pathway [30-32] (Figure 2). In addition, activation of the DNA damage checkpoint pathway inhibits Cdc20 activity by direct phosphorylation by Protein Kinase A (PKA) [33]. Achieving bi-polar attachment of chromosomes on the metaphase plate extinguishes the spindle checkpoint signal permitting securin (Pds1) ubiquitylation/destruction and anaphase to proceed [34]. A unified molecular model of how checkpoint proteins block APC-mediated ubiquitylation of securin has not been established. Recently, Mad3 has emerged as a key player in this process that both mediates $\mathrm{Cdc} 20$ degradation in prometaphase by an unknown mechanism [35-37] and acts as an APC/C pseudo-substrate inhibitor [38]. In G1, APC/ $\mathrm{C}^{\mathrm{Cdh} 1}$ and a proteasome independent mechanism induce Cdc20 proteolysis as the cells prepare for the initiation of DNA replication [28]. In addition to proteolysis, Cdc20 is again negatively regulated by PKA but at a 


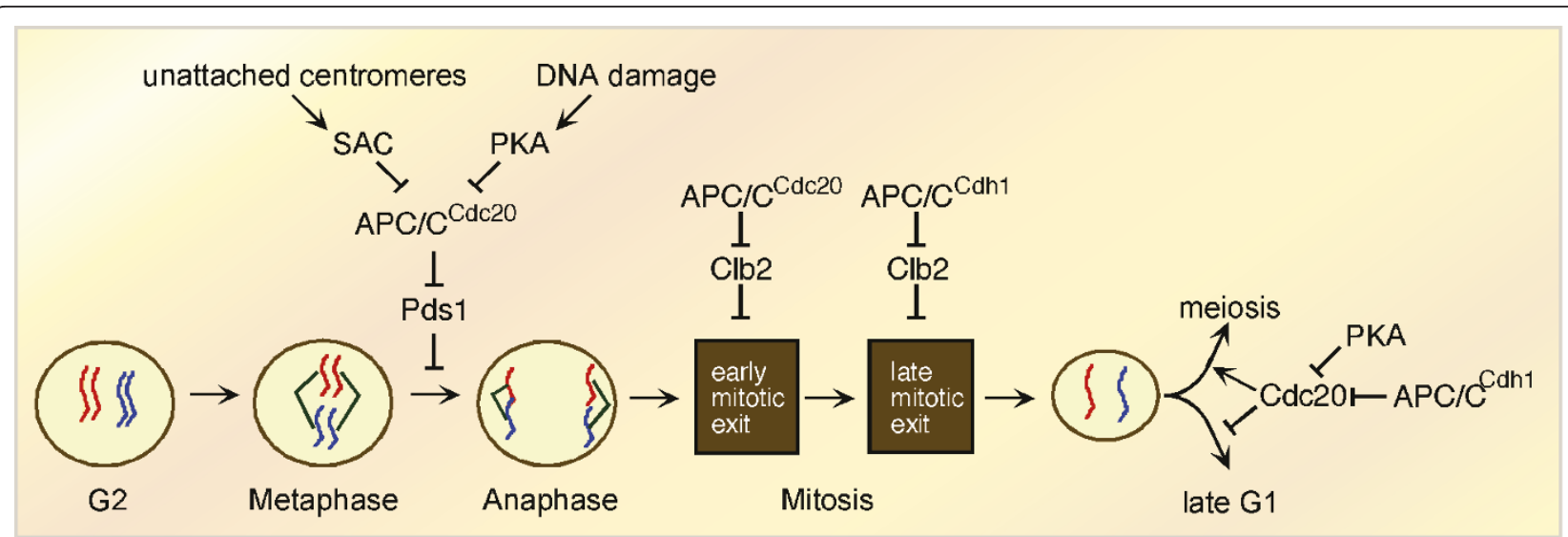

Figure 2 Regulation of the G2/M transition and mitotic exit by the APC/C. Destruction of Pds1 (securin) by $A P C / C^{C d c 20}$ triggers the metaphase-anaphase transition. Checkpoint pathways monitoring spindle attachment or DNA damage can inhibit APC/C Cdc20 activity by direct association of spindle assembly checkpoint (SAC) components or phosphorylation by PKA. The exit from mitosis initially requires the degradation of several regulatory proteins including the B-type cyclin Clb2 by APC/C $C^{\mathrm{Cd} 20}$. Final mitotic exit requires APC/C ${ }^{\mathrm{Cdh} 1}$ which continues Clb2 degradation to completion. APC/C $C^{C d h 1}$ remains active in G1 partially destroying $\mathrm{Cdc} 20$. The decision to enter meiosis occurs early in G1 and requires $\mathrm{APC} / \mathrm{C}^{\mathrm{Cdc} 20}$ destruction of Ume6. Inhibition of Cdc20 function by PKA phosphorylation drives the cell through $\mathrm{G} 1$ to reinitiate another round of mitotic cell division.

different site to prevent the initiation of meiosis (see below).

\section{$\mathrm{APC} / \mathrm{C}^{\mathrm{Cdc20}}$ activity is required for entry into the meiotic program}

To enter the meiotic program, cells exit the cell cycle early in G1 before the accumulation of the G1 cyclins [39]. The transition between mitotic and meiotic cell division requires the destruction of the transcriptional repressor Ume6 by $\mathrm{APC} / \mathrm{C}^{\mathrm{Cdc} 20}[10]$. Ume6 is a $\mathrm{C} 6$ zinc cluster DNA binding protein [40] that represses early meiotic genes during mitotic cell division in the presence of nitrogen and a fermentable carbon source (Figure 3, left panel). Under rich growth conditions, activated PKA phosphorylation of Cdc20 (at a site different than targeted following DNA damage) restricts $\mathrm{APC} / \mathrm{C}$ activity, possibly by preventing the interaction of Cdc20 with some of its substrates [33,41]. This model is consistent with the observation that Cdc20 and Ume6 do not associate under rich growth conditions [10]. Ume6 destruction has been divided into a two-step process. The first step partially degrades Ume6 and occurs in cultures growing in medium containing nitrogen and only a non-fermentable carbon source (Figure 3, middle panel). In this medium, PKA activity is reduced along with the inhibitory phosphorylation on Cdc20. This reduction in Ume6 levels results in a low level derepression of early meiotic genes. However, Ume6 destruction is not complete until cells are shifted to media lacking both nitrogen and a fermentable carbon source (Figure 3 , right panel). Under these conditions, the IME1 gene is transcribed and the association of its gene product with Ume6 completes $\mathrm{APC} / \mathrm{C}^{\mathrm{Cdc} 20}$ dependent destruction [10]. Once Ume6 destruction is complete, EMG transcription is induced and meiotic program is initiated. The mechanism for how Ime1 association mediates the final destruction of Ume6 is not known. However the presence of Ime1 stimulates Ume6 ubiquitylation by $\mathrm{APC} / \mathrm{C}^{\mathrm{Cdc} 20}$ in vitro (unpublished results). These findings suggest a model that $\mathrm{APC} / \mathrm{C}^{\mathrm{Cdc} 20}$ is retasked by the presence of Ime1 to complete Ume6 destruction. Recent studies indicate that APC/C regulation of post-mitotic differentiation programs may be more common than previously appreciated (reviewed in [42]). For example, the oncoprotein Sno, a negative regulator of the SMAD pathway, is destroyed in an APC/C dependent manner following TGF $\beta$ stimulation [43]. In addition, a post-mitotic role for the $\mathrm{APC} / \mathrm{C}$ has been observed in neurons $[43,44]$. Finally, in a system perhaps analogous to $\mathrm{APC} / \mathrm{C}^{\mathrm{Cdc} 20}$ and Ume6, destruction of the transcriptional repressor Id2 by $\mathrm{APC} / \mathrm{C}^{\mathrm{Cdh} 1}$ is required for exit from the mitotic cell cycle and to restrain axonal growth in neurons [45]. Therefore, the introduction of a developmentally regulated protein such as Ime 1 may provide a mechanism by which the substrate spectrum of the APC/C can be altered in the context of a differentiation program.

\section{$\mathrm{APC} / \mathrm{C}^{\mathrm{Cdc20}}$ is required for both meiotic divisions}

Evidence from many groups indicate that $\mathrm{APC} / \mathrm{C}^{\mathrm{Cdc} 20}$ triggers Pds1/Securin destruction prior to each nuclear division (Figure 4). For example, temperature sensitive $c d c 20$ mutants arrest at prophase I when cells are shifted to the restrictive temperature after meiotic entry 


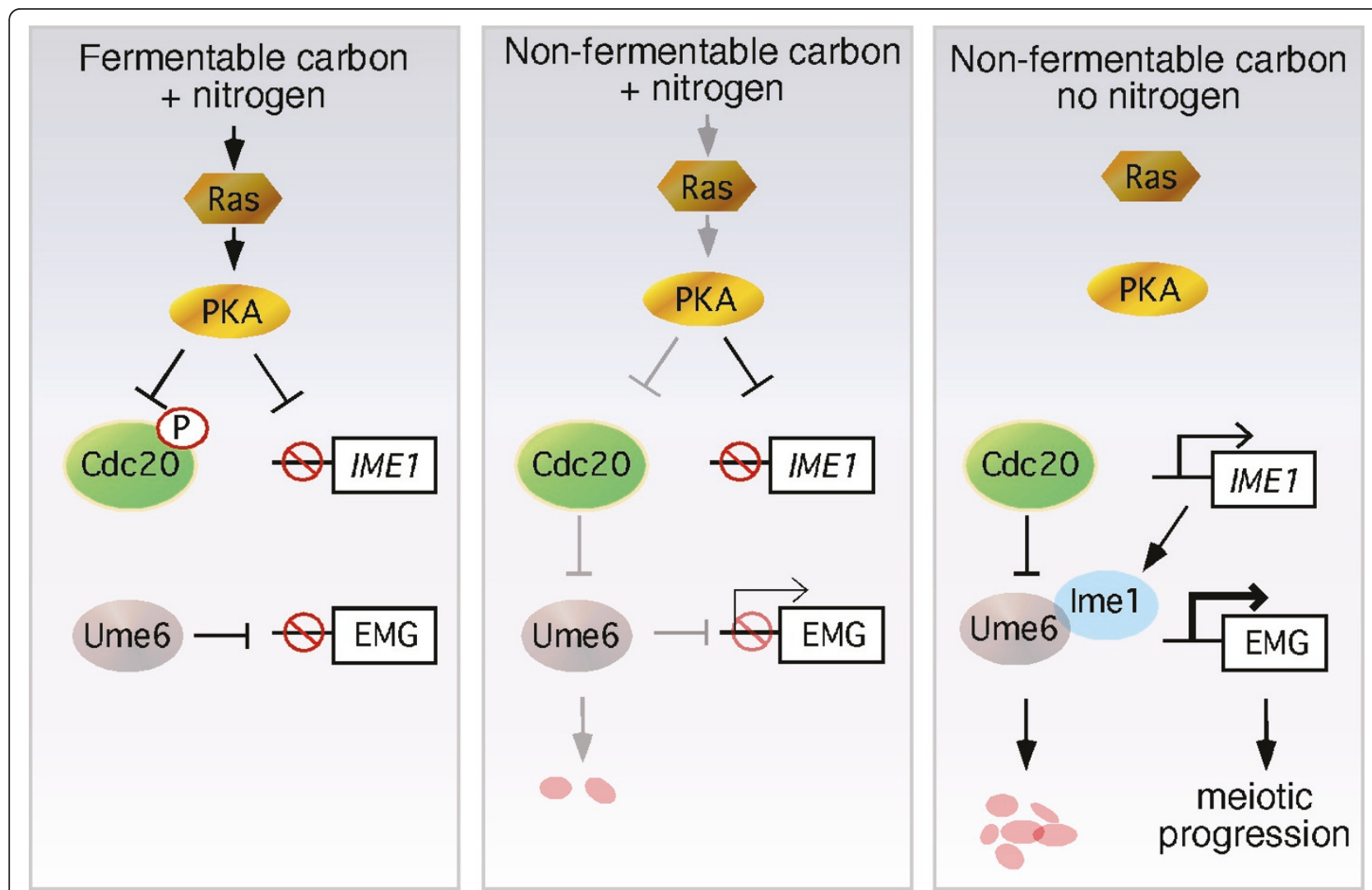

Figure $3 \mathrm{APC} / \mathrm{C}^{\mathrm{Cdc20}}$ mediated destruction of Ume6 is required for meiotic entry. Under rich growing conditions, PKA phosphorylation inhibits Cdc20 activity both protecting destruction of Ume6 is required for meiotic entry and preventing transcription of the meiotic inducer IMEI (left panel). Switching cultures to medium lacking a fermentable carbon source but containing nitrogen reduces PKA activity which permits partial Ume6 destruction (middle panel). Removing nitrogen allows Ime1 production which, along with fully active Cdc20, completely destroys Ume6 allowing early meiotic gene (EMG) induction and meiotic progression (right panel).

$[8,11]$. In addition, wild-type cells expressing a nondestructible allele of PDS1 also arrest at prophase I [46-48]. Lastly, single cell immunofluorescence studies revealed Pds1 proteolysis prior to both meiotic divisions [11]. Surprisingly, APC/C $\mathrm{C}^{\mathrm{Ama1}}$ also has the capability to destroy Pds1 during the meiotic divisions $[47,49]$. However, this destruction only occurs in cells lacking the APC/C inhibitor Mnd2 $[5,47,49]$.

\section{Multiple mechanisms regulate $\mathrm{APC} / \mathrm{C}^{\mathrm{Cdc20}}$ activity during meiosis}

The role for $\mathrm{APC} / \mathrm{C}^{\mathrm{Cdc20}}$ in both nuclear divisions imply that its activity must oscillate during this stage in development. Specifically, $\mathrm{APC} / \mathrm{C}^{\mathrm{Cdc} 20}$ must be inactive to permit Pds1 accumulation at metaphase I, activated to destroy it at anaphase I, then toggle off and on again to allow the second division to occur (Figure

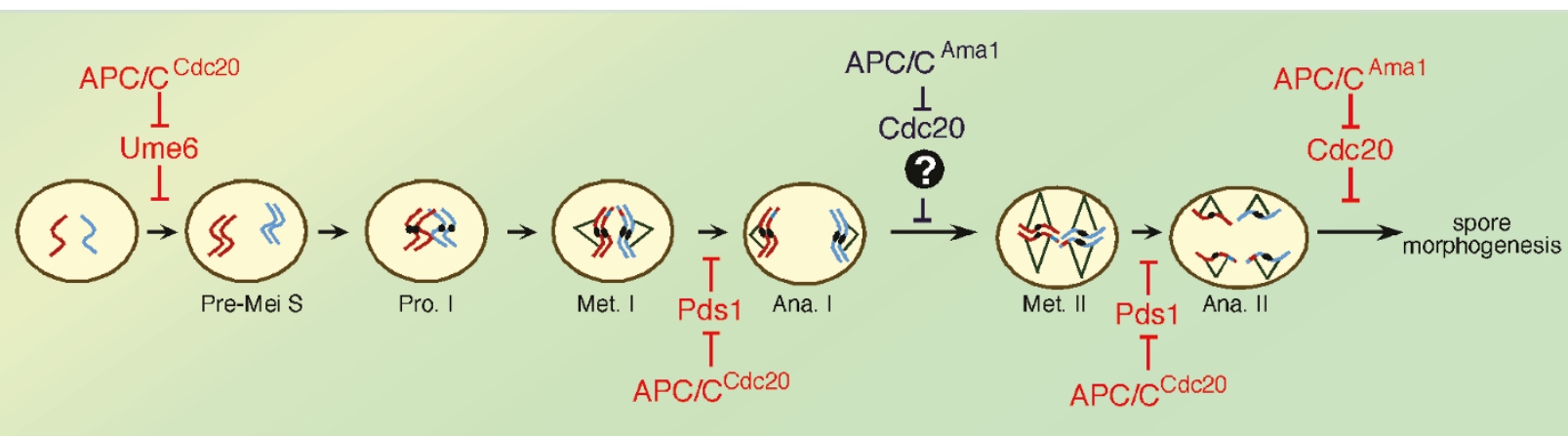

Figure 4 Regulation of meiotic progression by the APC/C. Diagram showing the known (red) and potential (purple) execution points for $\mathrm{APC} / \mathrm{C}^{\mathrm{Cdc} 20}$ and $\mathrm{APC} / \mathrm{C}^{\mathrm{Ama1} 1}$ activity during meiosis. 


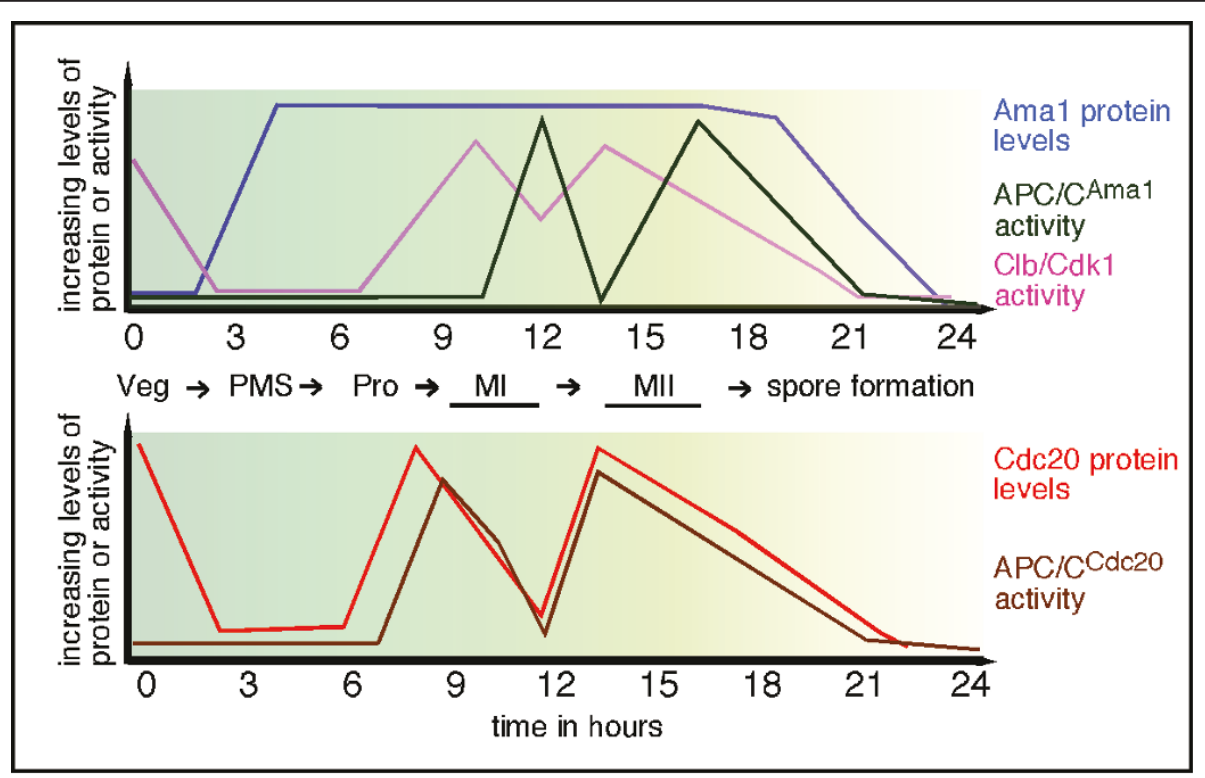

Figure 5 Regulation of Ama1 and Cdc20 activity during meiosis. The upper graph depicts the relationship between APC/C ${ }^{A m a 1}$ activity and Ama1 protein accumulation during meiosis. In addition, $\mathrm{Clb} / \mathrm{Cdk} 1$ activity is presented. The bottom graph illustrates the relationship between $\mathrm{APC} / \mathrm{C}^{\mathrm{Cdc} 20}$ activity and $\mathrm{Cdc} 20$ protein accumulation during meiosis.

5). $C D C 20$ expression is under the control of the NDT80 transcription factor and its mRNA is present during both meiotic divisions $[8,50]$. Using the presence or absence of an indirect immunofluorescence signal, Cdc20 levels were reported to dramatically fall between anaphase I and metaphase II [11] suggesting that protein destruction represented a key regulatory strategy. A potential clue for how Cdc20 levels are modulated came from the finding that $\mathrm{Cdc} 20$ is destroyed by APC/C $\mathrm{C}^{\mathrm{Ama1}}$ as cell exit meiosis II [8]. This result was different than G1 mitotic cells which utilize a combination of $\mathrm{APC} / \mathrm{C}$ dependent and independent mechanisms to accomplish this task. Interestingly, Mnd2-dependent inhibition of $\mathrm{APC} / \mathrm{C}^{\mathrm{Ama} 1}$ is mitigated prior to anaphase I, consistent with a role in Cdc20 degradation prior to metaphase II (Figure 4). However, it is not clear how APC/C $\mathrm{C}^{\text {Amal }}$ activity (Figure 5) would then be inhibited to allow subsequent accumulation of Cdc20 necessary for execution of the second division. In S. pombe, as well as higher eukaryotes, the $\mathrm{APC} / \mathrm{C}$ is inhibited at the MI/MII transition by specific endogenous inhibitors (reviewed in [51]). Therefore, one possibility is that a meiosis-specific inhibitor is synthesized to transiently curtail APC/ $\mathrm{C}^{\mathrm{Ama} 1}$ activity. Interestingly, cells deleted for $c d h 1$ fail to induce $\mathrm{Cdc} 20$ during meiosis yet display similar execution kinetics and spore viability as wild type [8]. This suggests a model in which Cdh 1 is indirectly required to keep Ama1 inactive until cells reach anaphase I exit.

\section{Regulation of Cdc20 as cells exit meiosis}

Upon exit from the second meiotic division, $\mathrm{APC} / \mathrm{C}^{\mathrm{Ama1}}$ mediates $\mathrm{Cdc} 20$ destruction through two degrons, a destruction box and a GxEN element [8]. In S. cerevisiae, Cdc20 destruction is not essential for meiotic progression as introducing a stabilized allele of $C D C 20$, under the control of the Ama1 promotor, did not affect spore production or viability [8]. This result suggests that $\mathrm{APC} / \mathrm{C}^{\mathrm{Cdc20}}$ can be inactivated by alternative mechanisms. For example, dephosphorylation of core APC/C subunits, possibly by PP1 or PP2A phosphatases, decreases APC/C activity (reviewed in [14]). In support of this idea, dephosphorylation of Cdc20 is important for release from metaphase II arrest in Xenopus egg extracts [52,53]. APC/C inactivation at the end meiosis is also critical for embryonic development in Drosophila [54]. Here, the meiosis-specific APC/C activator CORT (also known as CORTEX, [55]) is destroyed by APC/ $\mathrm{C}^{\mathrm{FZY}}$ (Cdc20p homologue) by completion of meiosis in the early embryo. Moreover, this degradation is destruction box dependent and hypothesized to be important for embryogenesis [54].

Finally, one interesting mechanistic question is how Cdc20 switches from being an activator to a substrate of the APC/C. Extensive studies have been devoted to a molecular understanding of APC/C substrate and activator recognition in mitotically dividing cells (reviewed in [56-58]). It is known that the conserved APC/C binding motifs (called C-box and IR motif) are required for APC/C binding of Cdc20, Cdh1 and Ama1 $[8,59,60]$. 
Cdc20 binding to the $\mathrm{APC} / \mathrm{C}$ via these motifs is not required for its destruction [8]. This suggests a model in which once $\mathrm{Cdc} 20$ is dissociated from the core $\mathrm{APC} / \mathrm{C}$, it is targeted for degradation by $\mathrm{APC} / \mathrm{C}^{\mathrm{Amal}}$.

\section{Concluding remarks}

It is clear that regulatory system governing meiotic development borrowed heavily from the system controlling mitotic cell division. For example, targeted ubiquitin mediated proteolysis of key regulatory factors still pushes meiosis and mitosis in one direction. In addition, these destruction pathways are governed by checkpoint surveillance systems to ensure the execution of one event before proceeding to the next. However, unique characteristics associated with meiosis such as haploidization, and the fact that meiosis is not a cycle but a linear differentiation pathway, necessitated significant modification of the mitotic regulatory pathways. At the onset, $\mathrm{APC} / \mathrm{C}^{\mathrm{Cdc} 20}$ dependent destruction of Ume6 sits at the decision point between meiosis and mitosis. Destroying Ume6 induces a specialized set of genes able to induce meiS phase under conditions (absence of nitrogen and other nutrients) that would prohibit mitotic S phase. Next, the ability to execute two nuclear divisions without an intervening $S$ phase requires delicate fine tuning of $\mathrm{APC} / \mathrm{C}^{\mathrm{Cdc} 20}$ activity to permit reassembly of the meiosis II spindle without allowing formation of the pre-replication complex on DNA replication origins. Finally, as post-meiotic cells can be dormant for extended time periods, the destruction of all three $\mathrm{APC} / \mathrm{C}$ activators protects against precocious re-entry into the mitotic cell cycle.

\section{Acknowledgements \\ This work was supported by ACS grant CCG106162 to K.F.C. and the National Institutes of Health grants CA90097 and GM57842 to R.S.}

\section{Authors' contributions}

KFC and RS wrote the manuscript together. Both authors read and approved the final manuscript.

\section{Competing interests}

The authors declare that they have no competing interests.

Received: 27 June 2011 Accepted: 1 August 2011

Published: 1 August 2011

\section{References}

1. Kupiec M, Byers B, Esposito RE, Mitchell AP: Meiosis and sporulation in Saccharomyces cerevisiae. In The molecular and cellular biology of the yeast Saccharomyces. Edited by: Pringle JR, Broach JR, Jones EW. Cold Spring Harbor, NY: Cold Spring Harbor Press; 1997:889-1036.

2. Szekvolgyi L, Nicolas A: From meiosis to postmeiotic events: homologous recombination is obligatory but flexible. Febs J 2010, 277:571-589.

3. Sakuno T, Watanabe Y: Studies of meiosis disclose distinct roles of cohesion in the core centromere and pericentromeric regions. Chromosome Res 2009, 17:239-249.

4. Klein F, Mahr P, Galova M, Buonomo SB, Michaelis C, Nairz K, Nasmyth K: A central role for cohesins in sister chromatid cohesion, formation of axial elements, and recombination during yeast meiosis. Cell 1999, 98:91-103.
5. Cooper KF, Egeland DE, Mallory MJ, Jarnik M, Strich R: Ama1p is a MeiosisSpecific Regulator of the Anaphase Promoting Complex/Cyclosome in yeast. Proc Natl Acad Sci USA 2000, 97:14548-14553.

6. McDonald CM, Cooper KF, Winter E: The Ama1-Directed AnaphasePromoting Complex Regulates the Smk1 Mitogen-Activated Protein Kinase During Meiosis in Yeast. Genetics 2005, 171:901-911.

7. Diamond AE, Park JS, Inoue I, Tachikawa H, Neiman AM: The anaphase promoting complex targeting subunit Ama1 links meiotic exit to cytokinesis during sporulation in Saccharomyces cerevisiae. Mol Biol Cell 2009, 20:134-145.

8. Tan GS, Magurno J, Cooper KF: Ama1p-activated anaphase-promoting complex regulates the destruction of $\mathrm{Cdc} 20 \mathrm{p}$ during meiosis II. $\mathrm{Mol}$ Biol Cell 2011, 22:315-326.

9. Smith KN, Penkner A, Ohta K, Klein F, Nicolas A: B-type cyclins CLB5 and CLB6 control the initiation of recombination and synaptonemal complex formation in yeast meiosis. Curr Biol 2001, 11:88-97.

10. Mallory MJ, Cooper KF, Strich R: Meiosis-specific destruction of the Ume6p repressor by the Cdc20-directed APC/C. Mol Cell 2007, 27:951-961.

11. Salah SM, Nasmyth K: Destruction of the securin Pds1p occurs at the onset of anaphase during both meiotic divisions in yeast. Chromosoma 2000, 109:27-34.

12. Peters JM: SCF and APC: the Yin and Yang of cell cycle regulated proteolysis. Curr Opin Cell Biol 1998, 10:759-768.

13. Tyers M, Jorgensen P: Proteolysis and the cell cycle: with this RING I do thee destroy. Curr Opin Genet Dev 2000, 10:54-64.

14. Harper JW, Burton JL, Solomon MJ: The anaphase-promoting complex: it's not just for mitosis any more. Genes \& development 2002, 16:2179-2206.

15. Peters JM: The anaphase promoting complex/cyclosome: a machine designed to destroy. Nat Rev Mol Cell Biol 2006, 7:644-656.

16. Wasch R, Robbins JA, Cross FR: The emerging role of APC/CCdh1 in controlling differentiation, genomic stability and tumor suppression. Oncogene 2010, 29:1-10.

17. Kramer ER, Scheuringer N, Podtelejnikov AV, Mann M, Peters JM: Mitotic regulation of the APC activator proteins $\mathrm{CDC} 20$ and $\mathrm{CDH} 1$ [In Process Citation]. Mol Biol Cell 2000, 11:1555-1569.

18. Rudner AD, Murray AW: Phosphorylation by cdc28 activates the Cdc20dependent activity of the anaphase-promoting complex. J Cell Biol 2000, 149:1377-1390.

19. Visintin R, Prinz S, Amon A: $C D C 20$ and $C D H 1$ : a family of substratespecific activators of APC-dependent proteolysis. Science 1997, 278:460-463

20. Cohen-Fix O, Koshland D: The anaphase inhibitor of Saccharomyces cerevisiae Pds1p is a target of the DNA damage checkpoint pathway. Proc Natl Acad Sci USA 1997, 94:14361-14366.

21. Nasmyth $\mathrm{K}$, Haering $\mathrm{CH}$ : Cohesin: its roles and mechanisms. Annual review of genetics 2009, 43:525-558.

22. Schwab M, Schulze Lutum A, Seufert W: Yeast Hct1 is a regulator of Clb2 cyclin protolysis. Cell 1997, 90:683-693.

23. Shirayama M, Zachariae W, Ciosk R, Nasmyth K: The Polo-like kinase Cdc5p and the WD-repeat protein Cdc20p/fizzy are regulators and substrates of the anaphase promoting complex in Saccharomyces cerevisiae. The EMBO journal 1998, 17:1336-1349.

24. Hildebrandt ER, Hoyt MA: Cell cycle-dependent degradation of the Sacharomyces cerevisae spindle motor Cin8p requires APCCdh1 and a bipartite destruction sequence. Mol Biol Cell 2001, 12:3402-3416.

25. Woodbury EL, Morgan DO: Cdk and APC activities limit the spindlestabilizing function of Fin1 to anaphase. Nature cell biology 2007, 9:106-112.

26. Juang Y-L, Huang J, Peters J-M, MCLaughlin ME, Tai C-Y, Pellman D: APCmediated proteolysis of Ase 1 and the morphogenesis of the mitotic spindle. Science 1997, 275:1311-1314

27. Crasta K, Huang P, Morgan G, Winey M, Surana U: Cdk1 regulates centrosome separation by restraining proteolysis of microtubuleassociated proteins. The EMBO journal 2006, 25:2551-2563.

28. Huang JN, Park I, Ellingson E, Littlepage LE, Pellman D: Activity of the APCCdh1 form of the anaphase promoting complex persists until $\mathrm{S}$ phase and prevents premature expression of Cdc20p. The Journal of biological chemistry 2001, 154:85-94.

29. Fang G, Yu H, Kirschner MW: Direct binding of CDC20 protein family members activates the anaphase-promoting complex in mitosis and G1. Molecular Cell 1998, 2:163-171. 
30. Minshull J, Sun H, Tonks NK, Murray AW: A MAP kinase-dependent spindle assembly checkpoint in Xenopus egg extracts. Cell 1994, 79:475-486.

31. Hwang LH, Lau LF, Smith DL, Mistrot CA, Hardwick KG, Hwang ES, Amon A, Murray AW: Budding yeast $\mathrm{Cdc} 20$ : a target of the spindle checkpoint. Science 1998, 279:1041-1044.

32. Zhang $Y$, Lees E: Identification of an overlapping binding domain on Cdc20 for Mad2 and anaphase-promoting complex: model for spindle checkpoint regulation. Mol Cell Biol 2001, 21:5190-5199.

33. Searle JS, Schollaert KL, Wilkins BJ, Sanchez Y: The DNA damage checkpoint and PKA pathways converge on APC substrates and Cdc20 to regulate mitotic progression. Nature cell biology 2004, 6:138-145.

34. Logarinho $E$, Bousbaa $\mathrm{H}$ : Kinetochore-microtubule interactions "in check" by Bub1, Bub3 and BubR1: The dual task of attaching and signalling. Cell cycle (Georgetown, Tex) 2008, 7:1763-1768.

35. Hardwick KG, Johnston RC, Smith DL, Murray AW: MAD3 encodes a novel component of the spindle checkpoint which interacts with Bub3p, Cdc20p, and Mad2p. J Cell Biol 2000, 148:871-882.

36. Pan J, Chen RH: Spindle checkpoint regulates Cdc20p stability in Saccharomyces cerevisiae. Genes \& development 2004, 18:1439-1451.

37. King EM, van der Sar SJ, Hardwick KG: Mad3 KEN boxes mediate both Cdc20 and Mad3 turnover, and are critical for the spindle checkpoint. PloS one 2007, 2:e342.

38. Burton JL, Solomon MJ: Mad3p, a pseudosubstrate inhibitor of APCCdc20 in the spindle assembly checkpoint. Genes \& development 2007, 21:655-667.

39. Colomina N, Gari E, Gallego C, Herrero E, Aldea M: G1 cyclins block the Ime1 pathway to make mitosis and meiosis incompatible in budding yeast. The EMBO journal 1999, 18:320-329.

40. Strich R, Surosky RT, Steber C, Dubois E, Messenguy F, Esposito RE: UME6 is a key regulator of nitrogen repression and meiotic development. Genes \& development 1994, 8:796-810.

41. Bolte M, Dieckhoff P, Krause C, Braus GH, Irniger S: Synergistic inhibition of $\mathrm{APC} / \mathrm{C}$ by glucose and activated Ras proteins can be mediated by each of the Tpk1-3 proteins in Saccharomyces cerevisiae. Microbiology (Reading, England) 2003, 149:1205-1216.

42. Qiao X, Zhang L, Gamper AM, Fujita T, Wan Y: APC/C-Cdh1: from cell cycle to cellular differentiation and genomic integrity. Cell cycle (Georgetown, Tex) 2010, 9:3904-3912

43. Teng FY, Tang BL: APC/C regulation of axonal growth and synaptic functions in postmitotic neurons: the Liprin-alpha connection. Cell Mol Life Sci 2005.

44. van Roessel P, Elliott DA, Robinson IM, Prokop A, Brand AH: Independent regulation of synaptic size and activity by the anaphase-promoting complex. Cell 2004, 119:707-718.

45. Lasorella A, Stegmuller J, Guardavaccaro D, Liu G, Carro MS, Rothschild G, de la Torre-Ubieta L, Pagano M, Bonni A, lavarone A: Degradation of Id2 by the anaphase-promoting complex couples cell cycle exit and axonal growth. Nature 2006, 442:471-474.

46. Shonn MA, McCarroll R, Murray AW: Requirement of the spindle checkpoint for proper chromosome segregation in budding yeast meiosis. Science 2000, 289:300-303.

47. Oelschlaegel T, Schwickart M, Matos J, Bogdanova A, Camasses A, Havlis J, Shevchenko A, Zachariae W: The yeast APC/C subunit Mnd2 prevents premature sister chromatid separation triggered by the meiosis-specific APC/C-Ama1. Cell 2005, 120:773-788.

48. Cooper KF, Mallory MJ, Guacci V, Lowe K, Strich R: Pds1p is required for meiotic recombination and prophase I progression in Saccharomyces cerevisiae. Genetics 2009, 181:65-79.

49. Penkner AM, Prinz S, Ferscha S, Klein F: Mnd2, an essential antagonist of the anaphase-promoting complex during meiotic prophase. Cell 2005, 120:789-801

50. Chu S, DeRisi J, Eisen M, Mulholland J, Botstein D, Brown PO, Herskowitz I: The transcriptional program of sporulation in budding yeast. Science 1998, 282:699-705

51. Pesin JA, Orr-Weaver TL: Regulation of $A P C / C$ activators in mitosis and meiosis. Annu Rev Cell Dev Biol 2008, 24:475-499.

52. Yudkovsky Y, Shteinberg M, Listovsky T, Brandeis M, Hershko A: Phosphorylation of Cdc20/fizzy negatively regulates the mammalian cyclosome/APC in the mitotic checkpoint. Biochemical and biophysical research communications 2000, 271:299-304.
53. Costanzo M, Nishikawa JL, Tang X, Millman JS, Schub O, Breitkreuz K, Dewar D, Rupes I, Andrews B, Tyers M: CDK activity antagonizes Whi5, an inhibitor of G1/S transcription in yeast. Cell 2004, 117:899-913.

54. Pesin JA, Orr-Weaver TL: Developmental role and regulation of cortex, a meiosis-specific anaphase-promoting complex/cyclosome activator. PLoS Genet 2007, 3:e202.

55. Chu T, Henrion G, Haegeli V, Strickland S: Cortex, a Drosophila gene required to complete oocyte meiosis, is a member of the Cdc20/fizzy protein family. Genesis 2001, 29:141-152.

56. Matyskiela ME, Morgan DO: Analysis of activator-binding sites on the APC/C supports a cooperative substrate-binding mechanism. Mol Cell 2009, 34:68-80.

57. Pines J: The APC/C: a smorgasbord for proteolysis. Mol Cell 2009, 34:135-136.

58. Yu H: Cdc20: a WD40 activator for a cell cycle degradation machine. $\mathrm{Mol}$ Cell 2007, 27:3-16.

59. Schwab M, Neutzner M, Mocker D, Seufert W: Yeast Hct1 recognizes the mitotic cyclin $\mathrm{Clb} 2$ and other substrates of the ubiquitin ligase APC. The EMBO journal 2001, 20:5165-5175.

60. Vodermaier HC, Gieffers C, Maurer-Stroh S, Eisenhaber F, Peters JM: TPR subunits of the anaphase-promoting complex mediate binding to the activator protein CDH1. Curr Biol 2003, 13:1459-1468.

doi:10.1186/1747-1028-6-16

Cite this article as: Cooper and Strich: Meiotic control of the APC/C:

similarities \& differences from mitosis. Cell Division 2011 6:16.

\section{Submit your next manuscript to BioMed Central and take full advantage of:}

- Convenient online submission

- Thorough peer review

- No space constraints or color figure charges

- Immediate publication on acceptance

- Inclusion in PubMed, CAS, Scopus and Google Scholar

- Research which is freely available for redistribution 